\title{
LANDASAN YURIDIS PERMENKUMHAM NOMOR 3 TAHUN 2017 DITINJAU DARI SUDUT TEORI DAYA LAKU HUKUM (GELTUNG)
}

(The Juridical Basis of Permenkumham Number 3 Year 2017

Review from The Perspective of Validity Theory (Geltung))

\author{
Irfan Iryadi \\ Awardee LPDP RI dan Mahasiswa Program Doktor Ilmu Hukum \\ Fakultas Hukum - Universitas Diponegoro \\ JIn. Imam Bardjo No 1 Kota Semarang - Jawa Tengah \\ Email: irfan.aceray@gmail.com
}

Naskah diterima: 4 Agustus 2017; revisi: 13 November 2017; disetujui: 15 November 2017

\begin{abstract}
Abstrak
Kajian daya laku hukum (geltung) adalah berbicara bagaimana sebuah aturan itu berlaku dalam penyelenggaraan negara. Tulisan ini bermaksud ingin mengkaji keberlakuan Peraturan Menteri Hukum dan Hak Asasi Manusia terkait honorarium jasa hukum notaris untuk pendirian perseroan terbatas bagi usaha mikro, kecil dan menengah yang berbasis pada teori hukum. Penulisan ini mengacu pada jenis penelitian normatif, dengan menggunakan studi kepustakaan, dengan pendekatan perundang-undangan dan pendekatan konsep, serta menggunakan analisis deskriptif. Melalui penulisan ini didapatkan bahwa kebijakan pemerintah terkait biaya notaris tersebut tidak mempunyai landasan yuridis keberlakuannya, oleh sebab tidak adanya landasan berpijak, dan aturan tersebut telah mengesampingkan norma hukum yang lebih tinggi diatasnya. Dengan demikian, disarankan agar setiap pelaksanaan kebijakan ditingkat Peraturan Menteri harus diperintahkan oleh Peraturan Perundang-undangan yang lebih tinggi atau dibentuk berdasarkan kewenangan yang tidak bertentangan dengan norma yang lebih tinggi.
\end{abstract}

Kata Kunci : notaris, honorarium, kepastian hukum

\section{Abstract}

Research of legal validity (geltung) discusses about the implementaion of a regulation in state management.This study examines the validity of The Ministry of Law and Human Rights Regulation (Permenkumham) related to the notary legal service payment for establishing limited liability corporation for micro businesses, small and medium enterprises in the perspective of legal theory. This is a normative research using literature studies with regulation and conceptual approach and using descriptive analysis. This research indicates that the government policy related to the cost of notary legal services has no legal basis to be implemented and has put aside the higher hierarchichal law. Thus, it is recommended that the implementation of a Ministerial Regulation should be ordered by higher law or formed by authority which are not against the higher law.

Keywords: notary, honorarium, certainty 


\section{A. Pendahuluan}

Lembaga notaris merupakan sebuah lembaga yang timbul dari kebutuhan dalam pergaulan sesama manusia yang menghendaki alat bukti baginya mengenai hubungan hukum keperdataan yang ada dan/atau terjadi diantara mereka. ${ }^{1}$ Munculnya lembaga notaris dilandasi kebutuhan akan suatu alat bukti yang mengikat selain alat bukti saksi. ${ }^{2}$ Selain itu, pembuatan akta otentik oleh lembaga notaris adalah sebagai upaya meminimalisir sifat manusia yang sering salah dan lupa, sehingga jika dicatatkan dapat mengeliminasi kesalahan atau kealpaan serta juga sebagai bukti diantara para pihak. ${ }^{3}$

Notaris dalam The International Union of the Latin Notariat (UINL) didefenisikan sebagai " $a$ legal professional specially designated to attest the acts and contracts that persons celebrate or perform, to draft the documents that formalize the latter and to give legal advice to those who require the services of his office. ${ }^{4}$ Sementara dalam Pasal 1 butir (1) Undang-undang Nomor 2 Tahun 2014 Tentang Perubahan Atas UndangUndang Nomor 30 Tahun 2004 Tentang Jabatan Notaris, Notaris didefenisikan sebagai pejabat umum yang berwenang untuk membuat akta autentik dan memiliki kewenangan lainnya sebagaimana dimaksud dalam Undang-Undang ini atau berdasarkan undang-undang lainnya.
Berdasarkan kedua defenisi itu, memberikan pemahaman kepada kita bahwa notaris merupakan sebuah jabatan profesional hukum yang secara khusus diberi kewenangan untuk membuat dokumen resmi (bersifat autentik) oleh negara menurut undang-undang. Selain itu, notaris juga dapat memberikan pendapat hukum (nasehat hukum) bagi para penghadap yang membutuhkan pelayanannya berdasarkan peraturan perundang-undangan yang berlaku.

Dewasa ini, kebutuhan masyarakat akan pelayanan notaris semakin mengalami perkembangan, dan masyarakat semakin menyadari arti pentingnya sebuah akta notaris. Deni K. Yusup menyebutkan bahwa masyarakat sekarang lebih mempunyai kesadaran hukum dalam melakukan hubungan-hubungan hukumnya, baik itu hubungan hukum dalam bidang perjanjian bisnis dan perbankan maupun kegiatan-kegiatan sosial lainnya yang menggunakan jasa notaris untuk membuat akta otentik yang mengikat para pihak dalam kegiatannya. $^{5}$

Terkait dengan pelayanan jasa notaris itu, Agustinus Andy Toryanto $^{6}$ dalam tulisannya mengkualifikasikan pelayanan jasa notaris dapat dibagi kedalam 2 (dua) jenis, yaitu pelayanan secara umum dan pelayanan secara khusus. Pelayanan secara umum adalah pelayanan yang dilakukan oleh notaris kepada klien secara biasa/

Muhammad Irnawan Darori, Hukum Kenotariatan; Pengaturan Jabatan Notaris Berdasarkan Undang-undang Nomor 30 Tahun 2004, (Yogyakarta; Genta Publishing, 2014), hlm 1.

2 Abdul Ghofur Anshori, Lembaga Kenotariatan Indonesia Perspektif Hukum dan Etika, (Yogyakarta; UII Press, 2009). hlm 7.

3 Habib Adji dan Muhammad Hafidh, Akta Perbankan Syariah Yang Selaras Dengan Pasal 38 UUJN-P, Edisi Revisi, (Semarang; Pustaka Zaman, 2014), hlm 1.

4 Pedro A Malavet, "Caunsel For The Situation; The Latin Notary, A Historical And Comparative Model”, Hasting Internasional and Comparative Law Review, Vol. 19: 389, (1996): 431.

5 Deni K. Yusup, "Peran Notaris Dalam Praktek Perjanjian Bisnis Di Perbankan Syariah (Tinjauan Dari Perspektif Hukum Ekonomi Syariah)", Jurnal Al 'Adalah, Vol. XXI, No. 4, (2015): 703.

6 Agustinus Andy Toryanto, "Konsep Ideal Pelayanan Jasa Notaris Terhadap Orang Tidak Mampu", Disertasi Program Doktor Ilmu Hukum Fakultas Hukum, Universitas Diponegoro; Semarang, (2011). hlm 2-3. 
wajar, yaitu pelayanan jasa notaris yang diminta oleh para pihak dan notaris memperoleh imbalan atas jasa yang telah ia berikan. Sedangkan pelayanan khusus adalah pelayanan yang diwajibkan kepada notaris untuk melayani masyarakat tertentu, yakni orang tidak mampu.

Bertolak dari kualifikasi tersebut, notaris dalam menyelenggarakan jabatan profesional ${ }^{7}$ dalam melayani masyarakat, tentunya tidak menafikan keberadaan uang sebagai imbalan setelah dia memberikan pelayanan kepada masyarakat. Akan tetapi, uang tersebut bukan sebagai tujuan utama dalam penyelenggaraan tugas pekerjaan notaris. Hal demikian dilakukan sebagai perwujudan dari nilai profesionalisme dalam pengembanan jabatan notaris. Terkait dengan hal ini, Abdul Ghofur Anshori memaparkan bahwa, suatu profesi (baca: jabatan profesional) tidak dijalankan sematamata berdasarkan uang, namun adanya suatu penghargaan (honorarium) mutlak diperlukan sebagai salah satu unsur dari profesionalisme. ${ }^{8}$ Selain itu, Habib Adji juga menjelaskan bahwa honorarium hanya diberikan kepada mereka yang menjalanakan tugas jabatan berdasarkan perundang-undangan, sedangkan succes fee diberikan kepada mereka yang menjalankan profesi. ${ }^{9}$ Dalam hal ini, Ghansham Anand, ${ }^{10}$ dengan bersandar pengertian dalam Ensiklopedia Nasional Indonesia menyebutkan bahwa honorarium berasal dari kata honor, artinya kehormatan, kemuliaan,tanda/ penghargaan semula mengandung pengertian balas jasa para nasabah atau klien kepada dokter, akuntan, pengacara dan notaris. Kemudian pengertian meluas menjadi uang imbalan atau jasa atau hasil pekerjaan seseorang yang tidak berupa gaji tetap, umpamanya honorarium untuk pengarang penerjemah, illustrator dan konsultan.

Berdasarkan uraian diatas, dapat dipahami bahwa notaris sebagai pengemban jabatan profesional, dalam memberikan pelayanan kepada masyarakat umum tidak memperoleh gaji atau upah dari pemerintah, kendati mereka diangkat dan diberhentikan oleh pemerintah yang berkuasa. Namun harus dipahami bahwa, notaris dalam pelaksanaan tugas pekerjaannya itu, tentunya juga mendapatkan honorarium sebagai imbalan atas pelayanan yang diberikannya kepada masyarakat yang membutuhkan pelayanannya. Honorarium

7 Dengan merujuk pada bentuk dan corak notaris menurut Izenic, Habib Adji menyimpulkan bahwa notaris di Indonesia merupakan suatu jabatan bukan profesi, atas dasar pencirian yakni: Pertama, akta yang dibuat dihadapan/oleh notaris fungsional mempunyai kekuatan sebagai alat bukti yang sempurna dan kuat serta mempunyai daya eksekusi; ; Kedua,notaris fungsional menerima tugasnya dari negara dalam bentuk delegasi dari negara; Ketiga, notaris di Indonesia (sebelumnya) diatur dalam Peraturan Jabatan Notaris (Regelement op het Notarisambt In Indonesia), Stb 1860-3. Dalam teks asli bahwa ambt adalah jabatan dan dalam UU no 30 Tahun 2004 disebut sebagai UU jabatan notaris, yang berarti mengatur hal-hal yang berkaitan dengan pelaksanaan jabatan notaris. Jadi bagaimana mungkin ambt yang berarti jabatan harus berubah menjadi profesi. Sebaliknya jika notaris di Indonesia ingin disebut atau dikelompokkan sebagai suatu profesi, maka terlebih dahulu kita harus membuat UU Profesi Notaris dan akibatnya notaris di Indonesia termasuk dalam kelompok notaris profesional. Lihat lebih lanjut dalam Habib Adjie, Hukum Notaris Indonesia; Tafsir Telematik Terhadap UU Nomor 30 Tahun 2004 Tentang Jabatan Notaris, (Bandung; Rafika Aditama, 2008). hlm 9-10.

$8 \quad$ Abdul Ghofur Anshori, Loc.Cit, hlm 33.

$9 \quad$ Habib Adji, Hukum Notaris Indonesia, Op.cit, hlm 108.

10 Ghansham Anand, “Karekteristik Jabatan Notaris di Indonesia dan Batas Tanggung Gugatnya”, Disertasi Program Doktor Ilmu Hukum Fakultas Hukum, Universitas Airlangga; Surabaya, (2013). Hlm. 189-190. 
itu merupakan hak notaris yang diperoleh berdasarkan ketentuan Pasal 36 Undang Undang Nomor 30 Tahun 2004 Tentang Jabatan Notaris.

Dalam perkembangannya sekarang ini, untuk mewujudkan program Pemerintah terkait kemudahan berusaha (ease of doing business)di sektor mikro, kecil dan menengah, Pemerintah melalui Kementerian Hukum dan Hak Asasi Manusia mengeluarkan Peraturan Menteri Hukum dan Hak Asasi Manusia Republik Indonesia Nomor 3 Tahun 2017 yang mengatur tentang biaya jasa hukum notaris untuk pendirian perseroan terbatas bagi usaha mikro, kecil dan menengah (selanjutnya disebut Permenkumham). ${ }^{11}$ Adanya aturan tersebut diharapkan dapat mewujudkan iklim investasi yang lebih baik dan dipercayai dapat mendongkrak taraf kesejahteraan masyarakat di Indonesia melalui pemotongan biaya jasa notaris untuk pendirian perseroan terbatas bagi usaha mikro, kecil dan menengah (UMKM). ${ }^{12}$ Menyikapi aturan hukum tersebut, notaris sebagai sebuah lembaga pelaksana undangundang, tentunya harus menyelenggarakan dan melaksanakan ketentuan tersebut dengan penuh tanggung jawab dan profesional.

Akan tetapi, lain ceritanya apabila Permenkumhan itu ditelaah dari sudut keberlakuan suatu norma hukum (geltung), dimana pemberlakuannya tidak konsisten dengan aturan main dalam pembentukan suatu peraturan perundang-undangan. Masalah keberlakuan hukum ini merupakan suatu hal yang amat penting dalam kontruksi pembentukan norma hukum di Indonesia. Demikian pentingnya, dibutuhkan konsistensi dan kejelasan dalam pemberlakuan norma hukum agar tidak menimbulkan tumpang tindih antar peraturan perundang-undangan dan demi tercapainya kepastian hukum.

Terkait dengan paparan diatas, Maria Farida Indrati menyebutkan bahwa setiap norma itu berlaku karena ia mempunyai "daya laku" (validitas) atau karena ia mempunyai keabsahan (validity/geltung). ${ }^{13}$ Dengan demikian, dalam menentukan arah kebijakan negara melalui perumusan aturan hukum positif, pembahasan mengenai keabsahan aturan sangat penting

11 Agus Nurgoho Yusup yang menjabat sebagai Pelaksana Harian (Plh) Direktur Jenderal Administrasi Hukum Umum (Dirjen AHU) Kementerian Hukum dan HAM menjelaskan bahwa inovasi ini adalah upaya mendorong kemudahan berusaha (Ease of Doing Business/EoDB), yang sudah ditetapkan Presiden Joko Widodo masuk dalam Paket Kebijakan Ekonomi IX.Lihat dalam http://portal.ahu.go.id/id/detail/75-berita-lainnya/1560biaya-notaris-untuk-pendirian-pt-cuma-rp-1-juta. (diakses 6 Oktober 2017). Selain itu, keinginan tersebut dapat juga dilihat dalam Konsideran "menimbang" Permenkumham Nomor 3 Tahun 2017, yang menyatakan bahwa untuk menunjang program pemerintah mengenai kemudahan berusaha di Indonesia, kemudahan memulai usaha dalam sektor usaha mikro, kecil dan menengah merupakan faktor utama yang harus dilakukan, karena dengan memberi kemudahan kepada pelaku usaha sektor usaha mikro, kecil dan menengah akan meningkatkan peringkat kemudahan berusaha di Indonesia.

12 Usaha Mikro Kecil Menengah memegang peranan yang sangat besar dalam memajukan perekonomian Indonesia. Selain sebagai salah satu alternatif lapangan kerja baru, UMKM juga berperan dalam mendorong laju pertumbuhan ekonomi pasca krisis moneter tahun 1997 di saat perusahaan-perusahaan besar mengalami kesulitan dalam mengembangkan usahanya. Saat ini,UKM telah berkontribusi besar pada pendapatan daerah maupun pendapatan negara Indonesia. Lihat dalam https://jateng.kemenkumham.go.id/berita-kanwil/beritautama/2842-workshop-pelayanan-kenotariatan (diakses 6 Oktober 2017)

13 Maria Farida Indrati, Ilmu Perundang-undangan; Jenis Fungsi dan Materi Muatan, (Yogyakarta; Kanisius, 2014), hlm 39. 
untuk diperhatikan oleh karena sangat approch) serta analisis bahan dilakukan secara berhubungan dengan asas kepastian hukum, ${ }^{14}$ deskriptif analisis.

termasuk didalamnya Permenkumham Nomor 3 Tahun 2017.

Melangkah dari uraian latar belakang diatas, maka untuk adanya konsistensi dalam penulisan, pembahasan terkait pembuatan Permenkumham itu akan difokuskan pada landasan yuridis saja. Oleh karena itu, melalui tulisan ini, penulis hendak memaparkan sedikit mengenai mengapa keberlakuan Permenkumham Nomor 3 Tahun 2017 perlu dievaluasi kembali? Kemudian, bagaimanakah langkah yang dapat ditempuh untuk menyelesaikan persoalan keberlakuan Permenkumham Nomor 3 Tahun 2017 untuk adanya kepastian hukum?

\section{B. Metode Penelitian}

Adapun tulisan ini merupakan tulisan yang bertipe penelitian normatif. Penelitian hukum jenis ini, acapkali hukum dikonsepkan sebagai apa yang tertulis dalam peraturan perundangundangan (law in books) atau hukum dikonsepkan sebagai kaidah atau norma yang merupakan patokan berperilaku manusia yang dianggap pantas. ${ }^{15}$ Oleh sebab tipe penelitian tersebut, bahan hukum yang menjadi rujukan adalah bahan hukum sekunder yang didukung oleh bahan hukum primer dan menggunakan pendekatan perundang-udangan (statute approch) dan pendekatan konsep (conceptual

\section{Pembahasan}

\section{Keberlakuan Permenkumham Nomor 3 Tahun 2017 Berbasis Teori Geltung}

Pada bagian ini, sebelum penulis menguraikan argumentasi mengenai mengapa Permenkumham Nomor 3 Tahun 2013 perlu dievaluasi keberlakuannya, ada baiknya penulis memaparkan sedikit mengenai sistem penormaan peraturan perundang-undangan di Indonesia. Hal demikian digunakan penulis sebagai fondasi awal untuk memudahkan penulis dalam menganalisis pokok permasalahan dalam tulisan ini.

Sebagaimana diketahui bahwa pada hakekatnya hukum tidak lain adalah sebagai pelindung kepentingan manusia yang berbentuk kaidah atau norma, ${ }^{16}$ yang berguna sebagai pedoman atau peraturan hidup yang menentukan bagaimana harus bertingkah laku dalam masyarakat agar tidak merugikan orang lain dan dirinya sendiri. ${ }^{17}$ Mengingat akan hal ini, posisi hukum menjadi sentral dan penting dalam mengatur ketertiban dalam masyarakat.

Hukum tampil dalam menserasikan pertemuan antar kebutuhan dan kepentingan warga masyarakat, baik yang sesuai ataupun yang saling bertentangan. ${ }^{18}$ Oleh karena itu, hukum harus mampu menjaga dan mengatur harkat, martabat manusia serta kehidupan

14 Dalam Penjelasan Undang Undang Nomor 28 Tahun 2008 Tentang Penyelenggaraan Negara Yang Bersih Dan Bebas Dari Korupsi, Kolusi, Dan Nepotisme, Pasal 3 Angka (1) menyatakan bahwa yang dimaksud dengan "Asas Kepastian Hukum" adalah asas dalam negarahukum yang mengutamakan landasan peraturan perundangundangan,kepatutan, dan keadilan dalam setiap kebijakan Penyelenggara Negara.

15 Amiruddin dan Zainal Asikin, Pengantar Metode Penelitian Hukum, (Jakarta; Rajawali Pers, 2014 ), hlm 118.

16 Sudikno Mertokusumo, Bunga Rampai Ilmu Hukum, (Yogyakarta; Liberty, 2010). hlm 1.

17 Sudikno Mertokusumo, Mengenal Hukum; Suatu Pengantar,(Yoyakarta; Liberty, 2008). hlm 4.

18 Soedjono Dirdjosisworo, Pengantar Ilmu Hukum, Cet 18 (Jakarta; Rajawali Pers, 2016), hlm 5. 
kemanusiaan dengan mengatur keseimbangan kepentingan semua pihak demi kesejahteraan nilai-nilai kemanusiaan. ${ }^{19}$ Tujuannya tidak lain adalah tertuju kepada kedamaian hidup antar pribadi (het recht wil de vrede) sebagaimana pernah diungkapkan Van Apeldoorn. ${ }^{20}$

Indonesia sebagai negara hukum, secara mutatis-mutandis memunculkan kewajiban bagi negara, untuk melaksanakan prinsip negara berkeadilan. ${ }^{21}$ Prinsip keadilan hukum dijamin dalam perundang-undangan di setiap negara beradab dewasa ini. ${ }^{22}$ Dalam hal ini, konsep kepastian hukum ${ }^{23}$ mendasari tujuan hukum, yaitu membentuk keadilan. ${ }^{24}$

Dalam hubungannya dengan sistem perumusan norma hukum di Indonesia, apabila dibandingkan dengan teori jenjang norma (stefentheorie) dari Hans Kelsen dan teori jenjang norma hukum (die theorie vom stufentordnung der rechtsnormem) dari Hans Nawiasky, dapat dilihat adanya cerminan dari kedua sistem norma tersebut dalam sistem norma hukum negara Republik Indonesia. ${ }^{25}$ Dalam hal ini, Pancasila merupakan norma dasar penyelenggaraan negara (staatsfundamentalnorm) dan menjadi sumber hukum tertinggi dalam hierarki pembentukan norma hukum dibawahnya. Dengan demikian, apabila ada keinginan untuk mereformasi aturan hukum, tentunya dengan tetap memperhatikan kaidah Pancasila yang merupakan kaidah penuntun dalam politik hukum nasional, artinya adanya larangan bagi munculnya hukum yang bertentangan dengan nilai-nilai Pancasila. ${ }^{26}$

Secara normatif, Pasal 7 ayat (1) Undangundang Nomor 12 Tahun 2011 Tentang Pembentukan Peraturan PerundangUndangan (selanjutnya disebut PPU), telah mengkontruksikan hierarki peraturan perundang-undangan dibawah Pancasila, yang kekuatan hukum Peraturan Perundangundangan tersebut sesuai dengan hierarkinya, berupa:

a. Undang-Undang Dasar Negara Republik Indonesia Tahun 1945;

b. Ketetapan Majelis Permusyawaratan Rakyat;

c. Undang-Undang/Peraturan Pemerintah Pengganti Undang-Undang;

d. Peraturan Pemerintah;

e. Peraturan Presiden

19 Sri Redjeki Hartono, "Perspektif Hukum Pada Era Teknologi”, Pidato Pengukuhan Jabatan Guru Besar Hukum Dagang Pada Fakulas Hukum Universitas Diponegoro, Semarang, (1995). hlm 10.

20 Kedamaian atau damai adalah suatu keadaan yang sebagai pengertian mencakup dua hal, yaitu ketertiban atau keamanan (orde) dan ketentraman atau ketenangan (rust). Orde menunjukkan pada hubungan atau komunikasi zahiriah, sementara rust menunjukkan pada keadaan bathiniah (Internal life). Lihat lebih lanjut dalam Purnadi Purbacaraka dan Soerjono Soekanto, Perihal Kaedah Hukum, Cet ke-6, (Bandung; PT Citra Aditya Bakti, 1993). HIm 19.

21 Yos Johan Utama, "Membangun Peradilan Tata Usaha Negara Yang Berwibawa”, Pidato Pengukuhan Jabatan Guru Besar Dalam Ilmu Hukum Pada Fakulas Hukum Universitas Diponegoro, di Semarang, (2010). hlm 5.

22 Ibid

23 Terkait dengan konsep kepastian hukum, Satjipto Rahardjo menjelaskan bahwa kepastian hukum bisa berupa suatu keadaan yang memenuhi tuntutan serta kebutuhan yang sangat praktis, yaitu adanya kaidah tertentu. Jadi dalam konteks tuntutan yang sangat praktis tersebut, yang dikehendaki adalah adanya peraturan hukum. Lihat dalam Satjipto Rahardjo, "Meningkatkan Kepastian Hukum dalam Rangka Pelaksanaan Keadilan Berdasarkan Pancasila”, Jurnal Hukum dan Pembangunan Universitas Indonesia Vol 18, No. 6 (1988) hlm 533-534.

24 FX Adji Samekto,Hukum Dalam Lintasan Sejarah, (Bandar Lampung; Indept Publishing, 2013), hlm 4.

25 Maria Farida Indrati, Op.Cit, hlm 57.

26 Moh Mahfud MD, Konstitusi dan Hukum Dalam Kontroversi Isu, (Jakarta; Rajawali Pers, 2012), hlm 38. 
f. Peraturan Daerah Provinsi; dan

g. Peraturan Daerah Kabupaten/Kota.

Sementara itu, dalam Pasal 8 ayat (1) dan (2) PPU disebutkan bahwa jenis Peraturan Perundang-undangan selain sebagaimana dimaksud dalam Pasal 7 ayat (1) tersebut mencakup peraturan yang ditetapkan oleh Majelis Permusyawaratan Rakyat, Dewan Perwakilan Rakyat, Dewan Perwakilan Daerah, Mahkamah Agung, Mahkamah Konstitusi, Badan Pemeriksa Keuangan, Komisi Yudisial, Bank Indonesia, Menteri, ${ }^{27}$ badan, lembaga, atau komisi yang setingkat yang dibentuk dengan Undang-Undang atau Pemerintah atas perintah Undang-Undang, Dewan Perwakilan Rakyat Daerah Provinsi, Gubernur, Dewan Perwakilan Rakyat Daerah Kabupaten/Kota, Bupati/ Walikota, Kepala Desa atau yang setingkat. Peraturan Perundang-undangan sebagaimana dimaksud tersebut, tetap diakui keberadaannya dan mempunyai kekuatan hukum mengikat sepanjang diperintahkan oleh Peraturan Perundang-undangan yang lebih tinggi atau dibentuk berdasarkan kewenangan. ${ }^{28}$

Adanya Pasal 8 itu dilatarbelakangi oleh pemikiran bahwa dalam praktik ketatanegaraan dan pemerintahan ditemui berbagai ketentuan yang bersifar regulatif, yang ditetapkan oleh badan dan/atau pejabat yang diberi wewenang untuk itu. ${ }^{29}$ Ketentuan ini merupakan hasil belajar dari pengalaman saat berlakunya TAP
MPR Nomor III/MPR/2000, yang secara limitatif menentukan bentuk dan jenis peraturan perundang-undangan, yang kemudian justru menimbulkan berbagai permasalahan dalam pelaksanaannya. ${ }^{30}$

Dalam konteks eksistensi Peraturan Menteri di Indonesia, maka dengan berpijak pada tugas dan fungsi Menteri sesuai dengan 17 UUD NRI 1945, Maria Farida Indrati merumuskan fungsi Peraturan Menteri sebagai berikut ini ${ }^{31}$ :

a. Menyelenggarakan pengaturan secara umum dalam rangka penyelenggaraan kekuasaan pemerintahan di bidangnya.

b. Menyelenggarakan pengaturan lebih lanjut ketentuan dalam peraturan presiden.

c. Menyelenggarakan pengaturan lebih lanjut ketentuan dalam Undang-undang yang tegas-tegas menyebutnya.

d. Menyelenggarakan pengaturan lebih lanjut ketentuan dalam Peraturan Pemerintah yang tegas-tegas menyebutnya.

Bertolak dari uraian diatas, telah kita dapatkan posisi Peraturan Menteri dalam sistem penormaan hukum di Indonesia. Kemudian, dalam rangka menjawab persoalan keberlakuan Permenkumham Nomor 3 Tahun 2013 berbasis teori geltung. Maka sebagaimana sudah pernah disinggung dimuka, bahwa sebagai upaya untuk meningkatkan kesejahteraan masyarakat, pemerintah Indonesia melakukan berbagai kebijakan, diantaranya adalah paket kebijakan

\footnotetext{
27 Penjelasan Pasal 8 ayat (1) menyebutkan bahwa, yang dimaksud dengan "Peraturan Menteri" adalah peraturan yang ditetapkan oleh menteri berdasarkan materi muatan dalam rangka penyelenggaraan urusan tertentu dalam pemerintahan.

28 Penjelasan Pasal 8 Ayat (2) menjelaskan bahwa yang dimaksud "berdasarkan kewenangan" sebagai penyelenggaraan urusan tertentu pemerintahan sesuai dengan ketentuan Peraturan Perundang-undangan.

29 Yuliandri, Asas-Asas Pembentukan Peraturan Perudang-Undangan Yang Baik; Gagasan Pembentukan UndangUndang Berkelanjutan, (Jakarta; Rajawali Pers, 2013), hlm 68.

30 Ibid.

31 Maria Farida Indrati,Op.Cit. hlm 225.
} 
kemudahan berusaha (ease of doing business) untuk pendirian perseroan terbatas bagi usaha mikro, kecil dan menengah melalui pemotongan biaya honorarium notaris.

Pasal 2 ayat (2) Peraturan Menteri Hukum Dan Hak Asasi Manusia Nomor 3 Tahun 2017 Tentang Biaya Jasa Hukum Notaris Untuk Pendirian Perseroan Terbatas Bagi Usaha Mikro, Kecil Dan Menengah mengatur tentang pengenaan biaya jasa hukum sebagai berikut:

a. Usaha Mikro, Kecil dan Menengah yang mempunyai modal dasar paling banyak Rp25.000.000,00 (dua puluh lima juta rupiah) dikenakan biaya sebesar Rp1.000.000,00 (satu juta rupiah), dengan rincian:

1) Rp. 300.000.- untuk persetujuan pemakaian nama perseroan dan pengesahan perseroan (per persetujuan).

2) Rp. 500.000,- untuk biaya akta notaris (per akta).

3) Rp. 200.000,- untuk biaya pengumuman dalam Berita Negara Republik Indonesia dan Tambahan Berita Negara Republik Indonesia (per pendirian).

b. Usaha Mikro, Kecil dan Menengah yang mempunyai modal dasar paling banyak Rp1.000.000.000,00 (satu miliar rupiah) dikenakan biaya sebesar Rp5.000.000,00 (lima juta rupiah)., dengan rincian:

1) Rp. 600.000.- untuk persetujuan pemakaian nama perseroan dan pengesahan perseroan (per persetujuan).

2) Rp. 4.000.000,- untuk biaya akta notaris (per akta).

3) Rp. 400.000,- untuk biaya pengumuman dalam Berita Negara Republik Indonesia dan Tambahan Berita Negara Republik Indonesia (per pendirian).

Kehadiran ketentuan diatas tentu saja akan semakin meningkatkan daya saing perekonomian Indonesia dan menaikkan taraf hidup masyarakat. Namun, sebagai negara hukum yang meletakkan hukum sebagai panglima dalam setiap kebijakan pemerintahan, prinsip kepastian hukum perlu juga untuk diperhatikan dalam pemberlakuan suatu norma hukum baru. Dalam hal ini, landasan yuridis suatu norma patut untuk diperhatikan dengan seksama untuk tidak adanya tumpang tindih peraturan sebagai akibat ketidak-konsistenan dasar hukum dalam pengundangannya menurut ajaran ilmu hukum.

Melangkah dari pemahaman sebelumnya, salah satu konsekuensi dari suatu norma itu sah berlaku adalah dikarenakan memiliki daya laku, maka dengan adanya hierarki peraturan perundang-undangan tersebut diatas, berkonsekuensi untuk adanya kewajiban dari norma yang lebih rendah yang berlaku, harus bersumber pada norma yang lebih tinggi. Dalam hal ini, Bagir Manan menyebutkan bahwa agar pembentukan undang-undang menghasilkan suatu undang-undang yang tangguh dan berkualitas, dapat digunakan 3 (tiga) landasan dalam menyusun undang-undang, yaitu: pertama, landasan yuridis (juridische gelding); kedua, landasan sosiologis (sociologiche gelding); dan ketiga, landasan filosofis. ${ }^{32}$

Selain itu, Jimly Asshiddiqie menyebutkan bahwa berkaitan dengan pembentukan aturan hukum yang baik, perumusan norma hukum itu selalu dipersyaratkan adanya 5 (lima) landasan

Yuliandri, Op.Cit. hlm 29. 
keberlakuan, yakni landasan filosofis, sosiologis, politis, dan yuridis yang bersifat mutlak, serta landasan adminstratif yang bersifat fakultatif. ${ }^{33}$ Dalam konsideran "Menimbang" yang harus dimuat adalah (i) landasan filosofis (ii) landasan sosiologis dan (iii) landasan politis. Sementara Konsideran "Mengingat" berisi landasan yuridis-normatif, sedangkan Konsideran "Memperhatikan" memuat landasan administratif yang bersifat fakultatif. ${ }^{34}$

Secara teoritis, khusus dalam konteks daya laku (geltung), keabsahan suatu norma itu sangat bersinggungan dengan landasan yuridis (juridische gelding) ${ }^{35}$ suatu norma hukum. Hal demikian merupakan legitimasi dalam merumuskan suatu norma hukum yang berlaku untuk umum. Menurut Maria Farida Indrati, daya laku (geltung) ini ada apabila norma itu dibentuk oleh norma yang lebih tinggi atau oleh lembaga yang berwenang membentukknya. ${ }^{36}$
Sementara itu, M. Solly Lubis $^{37}$ menjelaskan bahwa dalam hubungannya dengan perumusan norma oleh lembaga yang berwenang untuk membentuknya, yang ia sebut sebagai landasan yuridis dari segi formal, adalah landasan yang memberi kewenangan (bevoegdheid) bagi Instansi yang tertentu untuk membuat peraturan tertentu. Tanpa disebutkan dalam peraturan perundang-undangan sebagai landasan yuridis formal, seorang pejabat atau suatu lembaga/ badan adalah tidak berwenang (onbevoegdheid) mengeluarkan peraturan. Landasan yuridis formal selain menetapkan lembaga/badan yang berwenang membentuk, juga secara garis besar ditetapkan proses dan prosedur penetapannya. Jadi dengan demikian, jenis peraturan perundang-undangan serta lembaga/ badan yang berwenang membentuknya harus mempunyai landasan formal secara tegas dalam peraturan perundang undangan. Tanpa

33 Landasan filosofis menyatakan bahwasanya uu selalu mengandung norma-norma hukum yang di Idealkan (ideal norm) oleh suatu masyarakat ke arah mana cita-cita luhur kehidupan bermasyarakat dan bernegara hendak diarahkan; lebih lanjut, landasan kedua adalah landasan sosiologis yaitu bahwa setiap norma hukum yang dituangkan dalam uu haruslah mencerminkan tuntutan kebutuhan masyarakat sendiri akan norma hukum yang sesuai dengan realitas kesadaran hukum masyarakat; Kemudianlandasan politis yang dimaksud disini ialah bahwa dalam konsideran harus pula tergambar adanya sistem rujukan konstitusional menurut cita-cita dan norma dasar yang terkandung dalam UUD 1945 sebagai sumber kebijakan pokok atau sumber politik hukum yang melandasi pembentukan uu yang bersangkutan; Sementara, landasan yuridis dalam perumusan setiap uu haruslah ditempatkan pada bagian konstideran "mengingat"; Terakhir, landasan administratif, landasan ini lazimnya dalam praktik pembentukan peraturan perundang-undangan dimasukkan dalam konsideran "memperhatikan" dan bersifat "fakultatif" sesuai kebutuhan. Landasan ini berisi rujukan yang bersifat administratif dan tidak semua uu mencantumkan landasan ini. Lihat dalam Jimly Asshiddiqie, Perihal Undangundang, (Jakarta; Rajawali Pers, 2014), hlm 117-119.

$34 \quad$ Ibid, hlm 119.

35 Undang-Undang No. 12 Tahun 2011, dalam lampiran I menyebutkan bahwa landasan yuridis didefenisikan sebagai pertimbangan atau alasan yang menggambarkan bahwa peraturan yang dibentuk untuk mengatasi permasalahan hukum atau mengisi kekosongan hukum dengan mempertimbangkan aturan yang telah ada, yang akan diubah, atau yang akan dicabut guna menjamin kepastian hukum dan rasa keadilan masyarakat. Landasan yuridis menyangkut persoalan hukum yang berkaitan dengan substansi atau materi yang diatur sehingga perlu dibentuk Peraturan Perundang-Undangan yang baru. Beberapa persoalan hukum itu, antara lain, peraturan yang sudah ketinggalan, peraturan yang tidak harmonis atau tumpang tindih, jenis peraturan yang lebih rendah dari Undang-Undang sehingga daya berlakunya lemah, peraturannya sudah ada tetapi tidak memadai, atau peraturannya memang sama sekali belum ada.

36 Jimly Asshiddiqie, Ibid.

37 Mukhlis Taib, Dinamika Perundang-Undangan di Indonesia, (Bandung; Refika Aditama, 2017), hlm 34-35. 
landasan formal, maka prinsip negara berdasar atas hukum akan menjadi goyah.

Kemudian dalam hal norma itu mempunyai daya laku apabila dibentuk oleh norma yang lebih tinggi, atau yang ia sebut landasan yuridis dari segi material, yakni dasar hukum untuk mengatur hal-hal tertentu. Landasan yuridis material menunjuk kepada materi muatan tertentu yang harus dimuat dalam suatu peraturan peundang-undangan tertentu. Pembentuk peraturan menghendaki bahwa suatu materi tertentu hendaknya diatur dalam suatu peraturan peundang-undangan tertentu pula. Isi atau substansi suatu peraturan peundang-undangan harus sesuai dengan "wadahnya" atau jenis peraturan peundangundangan. Selain itu, isi suatu peraturan perundang-undangan tidak boleh bertentangan dengan isi peraturan perundang-undangan yang derajatnya lebih tinggi. ${ }^{38}$

Melihat uraian diatas,dalam konteks pengundangan Permenkumham, memang Peraturan Menteri tersebut memenuhi landasan yuridis formal, yakni aturan yang lahir atau dibuat oleh lembaga negara yang berwenang menyelenggarakan urusan pemerintahan di bidang hukum dan hak asasi manusia, sebagaimana dimaksud dalam Pasal 2 Peraturan Presiden Nomor 44 Tahun 2015 tentang Kementerian Hukum dan Hak Asasi Manusia. ${ }^{39}$ Akan tetapi, dalam hal Peraturan Menteri itu dihubungkan dengan landasan yuridis material, maka terjadilah ketidakkonsistenan dalam pengundangannya. Dalam hal ini, seharusnya Peraturan Menteri tersebut merupakan pengaturan lebih lanjut dari aturan-aturan yang lebih tinggi, yang mana keberlakuannya diakui sepanjang diperintahkan oleh Peraturan Perundang-undangan dan tentunya tidak bertentangan dengan norma yang lebih tinggi.

Terkait dengan hal diatas, Pembentuk undang-undang menghendaki bahwa suatu materi tertentu hendaknya diatur dalam suatu peraturan perundang-undangan tertentu pula. Dalam hal ini, pembentuk peraturan (norma diatasnya Peraturan Menteri) menghendaki bahwa suatu materi tertentu hendaknya diatur dalam suatu peraturan perundang-undangan tertentu pula, dalam hal ini Peraturan Menteri. Oleh karena itu, sehubungan dengan pokok persoalan dalam tulisan ini, adalah tidak tepat dasar hukumnya (juristische geltung) dalam pengundangan Permenkumham tersebut. Pemahaman ini didasari dalam pembuatan peraturan UUJN, tidak ada suatu ayat pun yang memerintahkan "ketentuan lebih lanjut mengenai honorarium notaris untuk kepentingan tertentu akan diatur dengan Peraturan Menteri," kendati didalam konsideran Permenkumham tersebut juga telah mengingat adanya Undang-Undang Nomor 30 Tahun 2004 tentang Jabatan Notaris

Selain itu, sepanjang pengetahuan penulis yang terbatas, yang merujuk pada konsideran "mengingat" Permenkumham tersebut, tidak ada satupun perintah darinorma yang lebihtinggi untuk mengharuskan turunnya Permenkumham tersebut. Padahal sebagaimana telah diuraian sebelumnya mengenai fungsi Peraturan Menteri, selain menyelenggarakan pengaturan secara umum dalam rangka penyelenggaraan

$38 \quad$ Ibid, hlm 36.

39 Peraturan tersebut berbunyi bahwa, Kementerian Hukum dan Hak Asasi Manusia mempunyai tugas menyelenggarakan urusan pemerintahan di bidang hukum dan hak asasi manusia untuk membantu Presiden dalam menyelenggarakan pemerintahan negara. 
kekuasaan pemerintahan di bidang hukum, juga harus dibentuk sepanjang diperintahkan oleh Peraturan Perundang-undangan yang lebih tinggi. Hal demikian tentu juga dengan tetap memperhatikan eksistensi norma yang lebih tinggi diatasnya, sehingga tidak terjadi pertentangan norma.

Bertolak dari uraian diatas, sebagai akibat tidak dipenuhinya landasan yuridis dalam pembentukan sebuah norma hukum, maka dapat dikatakan bahwa Permenkumham tersebut telah mengenyampingkan keberadaan norma diatasnya, yakni UUJN. Padahal didalam UUJN, Pasal 36, yang mengatur mengenai honorarium notaris menyebutkan bahwa notaris berhak menerima honorarium atas jasa hukum yang diberikan sesuai dengan kewenangannya. ${ }^{40}$ Dengan demikian, hadirnya ketentuan tersebut telah memunculkan ketidakjelasan hukum, sehingga memerlukan evaluasi untuk adanya kepastian hukum. Dalam hal ini, meminjam pendapatnya Budiman Ginting ${ }^{41}$ bahwa yang dimaksud dengan kepastian hukum adalah adanya konsistensi peraturan dan penegakan hukum di Indonesia. Konsistensi peraturan ditunjukkan dengan adanya peraturan yang tidak saling bertentangan antara satu peraturan dengan peraturan yang lain, dan dapat dijadikan pedoman untuk suatu jangka waktu yang cukup, sehingga tidak terkesan setiap pergantian pejabat selalu diikuti pergantian peraturan yang bisa saling bertentangan.

\section{Keberlakuan Permenkumham Nomor 3 Tahun 2017 Untuk Adanya Kepastian Hukum}

Terkait dengan munculnya tulisan ini dan dengan tidak bermaksud mendeskreditkan kebijakan Pemerintah dalam rangka meningkatkan kesejahteraan masyarakat dengan memberikan kemudahan berusaha kepada pelaku usaha sektor usaha mikro, kecil dan menengah. Penulis percaya bahwa kepastian hukum itu dibutuhkan untuk adanya landasan berpijak (legitimasi) dan meminimalisir kekuasaan yang absolut dengan jalan menciptakan aturan yang responsif terhadap masyarakat. Tujuannya tidak lain adalah untuk mewujudkan tujuan negara Indonesia sebagaimana diamanahkan dalam Pembukaan Undang Undang Dasar Negara Republik Indonesia Tahun 1945.

Dalam rangka mencapai tujuan tersebut, tentunya juga harus diimbangi dan dijunjung

40 Ketentuan mengenai honorarium notaris masih merujuk pada undang-undang yang lama dikarenakan undangundang Nomor 2 Tahun 2014 Tentang Perubahan Atas Undang-Undang Nomor 30 Tahun 2004 Tentang Jabatan Notaris tidak merubah terkait dengan honorarium notaris, sehingga ketentuan mengenai honorarium notaris tetap berpedoman pada undang-undang yang lama. Dalam hal ini, besarnya honorarium yang diterima oleh Notaris didasarkan pada nilai ekonomis dan nilai sosiologis dari setiap akta yang dibuatnya. Nilai sosiologis ditentukan berdasarkan fungsi sosial dari objek setiap akta dengan honorarium yang diterima paling besar Rp 5.000.000,00 (lima juta rupiah). Sementara nilai ekonomis ditentukan dari objek setiap akta sebagai berikut:

a. sampai dengan Rp100.000.000,00 (seratus juta rupiah) atau ekuivalen gram emas ketika itu, honorarium yang diterima paling besar adalah 2,5\% (dua koma lima persen);

b. di atas Rp 100.000.000,00 (seratus juta rupiah) sampai dengan Rp. 1.000.000.000,00 (satu miliar rupiah) honorarium yang diterima paling besar 1,5\% (satu koma lima persen); atau

c. di atas Rpl.000.000.000,00 (satu miliar rupiah) honorarium yang diterima didasarkan pada kesepakatan antara Notaris dengan para pihak, tetapi tidak melebihi $1 \%$ (satu persen) dari objek yang dibuatkan aktanya.

41 Budiman Ginting, "Kepastian Hukum dan Implikasinya Terhadap Pertumbuhan Investasi di Indonesia", Pidato Pengukuhan Jabatan Guru Besar Tetap dalam Bidang Hukum Investasi Pada Fukultas Hukum Universitas Sumatera Utara, Medan, (2008): 2. 
tinggi oleh semua aparat pelaksana hukum di Indonesia, termasuk didalamnya para notaris Indonesia. Hal demikian didasari pada pemahaman profesionalisme, dimana bagi setiap profesional hukum, dalam bekerja tidak semata-mata berpijak pada materi (uang) yang diperoleh, akan tetapi juga, harus bisa mewujudkan tujuan negara. Dalam hal ini, notaris sebagai sebuah jabatan, wajib juga bertindak profesional (profesional dalam pikiran dan tindakan) dalam melaksanakan tugas jabatannya, sesuai dengan standar jabatan yang diatur dalam UUJN, yaitu memberikan pelayan yang sebaik-baiknya pada masyarakat. ${ }^{42}$

Terkait dengan istilah profesional bagi sebuah jabatan tersebut, penulis berpandangan bahwa istilah profesional itu dapat dikualifikasan kedalam 2 (dua) pengertian: Pertama, profesional dalam arti luas, yakni semua kegiatan pelayanan masyarakat, baik dalam arti jabatan (ambt) maupun pekerjaan (bereoep) harus mengemban sikap profesional dalam segala aspek kegiatannya. Kedua, profesional dalam arti sempit, yakni profesional hanya disematkan pada pekerjaan (bereoep) yang menjual jasa profesional tertentu dan diangkat serta diberhentikan oleh organisasinya, yang dikenal dengan istilah profesi, seperti akuntan, pengacara, dokter dll. Melihat kualifikasi ini, dapat disimpulkan bahwa jabatan notaris juga termasuk kedalam para pekerjaan profesional sebagaimana dimaksud oleh Soetandyo Wignjosoebroto mengenai kualifikasi pekerjaan profesional. ${ }^{43}$ Oleh karena itu, notaris juga telah tunduk pada nilai-nilai moralitas umum (common morality) dalam penyelenggaraan jabatannya.

Notaris sebagai profesional hukum sebagaimana uraian Arief Hidayat, yang menyebukan bahwa dalam berhukum itu hanya ada 2 (dua), yaitu pembentukan hukum dan pelaksanaan atau penegakan hukum, ${ }^{44}$ tentu dalam melaksanakan tugas dan fungsinya sebagai pejabat umum harus bertindak sesuai garis kebijakan negara sebagaimana diatur dalam hukum positif. Terkait dengan tugas jabatan notaris ini, Prof Mr. J.M. Polak (1973),

Habib Adji, Hukum Notaris Indonesia... Ibid. HIm 10

43 Soetandyo Wignjosoebroto telah mengkualifikasikan pekerjaan profesional itu sekurang-kurangnya ada tiga kriteria ciri yang secara mutlak harus dimiliki yakni:

a. Setiap kerja berkualifikasikan profesional itu harus merefleksikan adanya iktikad pekerjaannya yang dinyatakan dalam suatu ikrar atau sumpah dimuka umum (to profess) untuk merealisasikan suatu kebajikan yang diakui dan dijunjung tinggi oleh masyarakat.

b. Adanya penguasaan atas suatu kemahiran teknis bermutu tinggi yang dapat dipakai untuk merealisasikan kebajikan tersebut dengan amat baik dengan meluangkan sebagian dari masa hidupnya untuk mengikuti pendidikan dan pelatihan bertahun-tahun yang eksekutif dan berat guna menggapai keahlian tinggi yang diperlukan.

c. Ukuran ada tidaknya profesionalisme adalah hadirnya kesediaan para pekerja profesional secara nyata untuk menundukkan diri secara rela dan ikhlas pada kontrol organisasi atau korps sesamanya, berdasarkan seperangkat norma etik yang dituliskan (kode etik), yang dikembangkan dan disepakati bersama didalam organisasi. Lihat dalam Soetandyo Wignjosoebroto, Hukum Dalam Masyarakat; Perkembangan dan Masalah, Cet 2, (Malang; Bayumedia Publishing, 2008), hlm 212-214

Arief Hidayat, "Konsep dan Implementasi Negara Hukum Pancasila Dalam Mengatasi Permasalahan Hukum Nasional", Ceramah Kunci Ketua Mahkamah Konstitusi dalam Seminar Nasional "Konsep dan Implementasi Negara Hukum Pancasila Dalam Mengatasi Permasahanan Hukum Nasional" di Semarang, (tanggal 30 September (2017) di Semarang. hlm 7. 
membedakan tugas jabatan notaris dalam 3 (tiga) kategori/model berupa ${ }^{45}$ :

a. Ambtelijke model yakni notaris dalam menjalankan tugasnya membuat aktaakta otentik, baik karena diperintahkan oleh undang-undang maupun atas permintaan mereka yang menghendaki jasa pelayanannya, diharapkan dapat memenuhi kebutuhan masyarakat akan kepastian hukum.

b. Rechterlijke model, fungsi ini menuntut kepada notaris untuk didalam melaksanakan tugas jabatannya memberikan pelayanan/ jasanya kepada pihak-pihak sejauh mungkin menghindarkan terjadinya sengketa dikemudiannya.

c. Rechtshulp model, yakni notaris mempunyai kewajiban untuk memberikan peneranganpenerangan yang lengkap dan jelas mengenai akibat-akibat hukum dari tiap-tiap perjanjian yang dibuatnya. Dalam hubungan ini, notaris terpanggil untuk melindungi pihak-pihak yang lemah baik karena kedudukan ekonomi maupun pengetahuan mengenai hukum.

Bertolak dari uraian fungsi notaris tersebut, dapat dikatakan bahwa sebagai profesional hukum, notaris juga memegang peranan penting dalam mewujudkan tujuan negara. Oleh karena itu, notaris sebagai tenaga profesional $^{46}$ yang wewenangnya diberikan oleh undang-undang, mempunyai kewajiban untuk ikut menyukseskan kebijakan pemerintah dalam rangka mewujudkan tujuan negara. Bahkan dewasa ini, dalam lingkup Teknologi dan Informasi, peran notaris di Belanda telah menjadi pihak ketiga terpercaya dalam suatu transaksi elektronik (trusted third party) atau menjadi escrow untuk source-code software komputer. ${ }^{47}$

Selain itu, notaris juga berperan apabila dimintai pendapatnya terkait hukum kenotariatan, baik didalam pengadilan (sebagai saksi ahli atau sebagai saksi akta) maupun diluar pengadilan (sebagai staf ahli dalam perumusan suatu kebijakan yang berkaitan dengan jabatannya atau sebagai pejabat umum). Kemudian, notaris juga berperan dalam penyeberluasan pemahaman akan berbagai peraturan perundang-undangan kepada masyarakat melalui nasehat hukum (advice) dalam pelayanannya terkait suatu perbuatan hukum dalam bidang keperdataan.

Hal diatas didasari pada bengkaknya jumlah regulasi di Indonesia yang menuntut untuk adanya profesional hukum yang mengerti dan paham lika-liku aturan hukum di Indonesia. Dengan demikian, sesuai dengan kontruksi legal notification theory, yang menyebutkan bahwa suatu peraturan perundang-undangan yang telah diundangkan/diumumkan lebih diketahui serta isi dan maksud-maksud yang terkandung didalamnya lebih dimengerti/dipahami oleh khalayak ramai melalui penyebarluasan

45 Soetomo Ramelan, Peranan Notaris Dalam Pembangunan Hukum, Jurnal Hukum dan Pembangunan Universitas Indonesia", Vol 16, No 4, (1986), hlm 354-355.

46 Menurut Abdul Manan, tenaga profesional ialah tenaga yang benar-benar memiliki keahlian dan keterampilan dengan sikap mental yang terpuji dan dengan keahlian dan keterapilannya itu, ia dapat menjawab segala persolan yang timbul dalam kehidupan masyarakat. Lihat dalam Abdul Manan, Aspek-aspek Pengubahan Hukum, (Jakarta; Kencana, 2005), hlm 154.

47 Edmon Makarim, Notaris dan Transaksi Elektronik; Kajian Hukum Tentang Cybernotary atau Electronic Notary, (Jakarta; Raja Grafindo,2013) hlm 114. 
pemahaman peraturan perudang-undangan, ${ }^{48}$ termasuk didalamnya disebarkan oleh notaris.

Mengingat berbagai peran dan fungsi notaris lainnya sebagai pelaksana undangundang, menjadi sebuah keharusan kepada negara, dalam hal ini pemerintah, untuk merumuskan suatu kebijakan dalam bentuk norma hukum juga dengan memperhatikan segala aspek hukum dalam pembentukan peraturan perundang-undangan yang baik. Hal ini dikarenakan apabila kaburnya landasan yuridis dalam pembentukan sebuah norma hukum,maka norma tersebut menjadi batal, sehingga berimplikasi kepada notaris yang sedang berpraktek tidak serta merta terikat untuk mengikuti norma hukum tersebut dengan alasan tidak adanya kepastian hukum. Terkait hal ini, Bagir Manan menyebutkan bahwa ${ }^{49}$ :

\begin{abstract}
"Setiap pembentukan peraturan perundangundangan harus mempunyai landasan yuridis atau dasar yuridis yang jelas. Tanpa landasan atau dasar yuridis, peraturan perundangundangan akan batal demi hukum atau dapat dibatalkan. Landasan atau dasar yuridis pembentukan peraturan perundangundangan adalah peraturan perundangundangan tertentu. Dengan perkataan lain, setiap pembentukan peraturan perundangundangan harus dapat menunjukkan secara jelas peraturan perundang-undangan tertentu yang menjadi dasarnya".
\end{abstract}

Dengan demikian, langkah yang perlu dilakukan adalah dengan melakukan pengujian oleh pihak yang berkepentingan. Dalam hal ini, pada dasarnya pengujian peraturan perundangundangan dapat dilakukan melalui 3 (tiga) prosedur, yaitu: pengujian oleh pejabat atau badan administrasi (executive review), pengujian oleh badan yang sifatnya politik (legislative review) dan pengujian oleh badan peradilan (judicial review)..$^{50}$ Dalam hal ini, menilik ketentuan mengenai pengujian peraturan perundang-undangan, Pasal 9 ayat (1) dan (2) Undang-Undang Nomor 12 Tahun 2011, telah memuat ketentuan yang bahwasanya dalam hal suatu Undang-Undang diduga bertentangan dengan Undang-Undang Dasar Negara Republik Indonesia Tahun 1945, pengujiannya dilakukan oleh Mahkamah Konstitusi. Sementara dalam hal suatu Peraturan Perundang-undangan dibawah Undang-Undang diduga bertentangan dengan Undang-Undang, pengujiannya dilakukan oleh Mahkamah Agung.

Bertolak dari kontruksi ketentuan diatas, Retno Saraswati ${ }^{51}$ menjelaskan bahwa dalam hubungannya dengan Paraturan Menteri yang dalam hierarki peraturan peraturanperundangan mempunyai kedudukan yang lebih rendah dibandingkan undang-undang, sebenarnya pengujiannya dapat dilakukan oleh Mahkamah Agung, walaupun tidak termasuk kedalam jenis peraturan yang ada dalam hierarki peraturan perundang-undangan. Namun terkait dengan Peraturan Menteri tersebut, mekanisme itu tidak dipergunakan. Oleh karena itu, beliau dalam pidatonya pengukuhannya menawarkan mekanisme yang tepat dan efektif serta dalam kerangka penguatan sistem presidensial, maka mekanisme pengujian dilakukan oleh Presiden

48 Astim Riyanto, "Notifikasi Hukum Konstitusi Melalui Pendidikan”, Jurnal Hukum dan Pembangunan Universitas Indonesia, Vol 38 Nomor 1, (2008), hlm 80.

49 Mukhlis Taib, Op.Cit, hlm 38.

50 Retno Saraswati, "Daulat Presiden Dalam Kabinet Presidensial”, Pidato Pengukuhan Jabatan Guru Besar Bidang Ilmu Hukum Tata Negara Pada Fakulas Hukum Universitas Diponegoro, di Semarang, (2016), hlm 49.

51 Ibid, hlm 50-51. 
sendiri, Presidenlah yang membatalkan Peraturan Menteri.

Selanjutnya beliau memaparkan bahwa mengingat banyak problem terkait dengan Peraturan Menteri, maka pembatalan peraturan menteri oleh Presiden tersebut dapat dilakukan manakala ${ }^{52}$ :

a) Peraturan Menteri tersebut bertentangan dengan peraturan Presiden atau peraturan perundang-undangan yang lebih tinggi kepentingannya dan/atau kesusilaan.

b) Peraturan Menteri tersebut tidak singkron dengan peraturan menteri yang lain, supaya tidak menimbulkan permasalahan hukum terutama dilevel pelaksanaan maupun di level daerah.

c) Peraturan Menteri yang mengatur mengenai hal-hal yang tidak sesuai dengan kebijakan Presiden.

Melihat pemahaman diatas, sebenarnya sangat berguna untuk mengukuhkan kepastian hukum dalam setiap kelahiran Peraturan Menteri, yang mana Presiden selaku kepala pemerintahan dapat menimalisir bahkan membatalkan Peraturan Menteri yang tidak jelas dasar yuridisnya sebagai akibat ketidakcermatan dalam perumusan dasar hukum pemberlakuan peraturan menteri. Selain pengujian, langkah lainnya yang dapat dilakukan adalah dengan mengevaluasi landasan yuridis Peraturan Menteri tersebut oleh instansi yang mengeluarkannya dengan melakukan perubahan peraturan, tentunya dengan mencarikan landasan berpijak yang selevel dengan UUJN untuk dijadikan sebagai dasar hukum yang tepat dalam pengundangannya.

\section{Penutup}

Peraturan Menteri Hukum dan HAM (Permenkumham) tersebut hanyalah pelaksanaan kebijakan pemerintah terkait ease of doing business demi meningkatkan kesejahteraan masyarakat di sektor mikro, kecil dan menengah, namun belum didasari dengan landasan yuridis yang memadai dalam pembentukannya. Dalam hal ini, landasan yuridis dari segi material yang mengatur mengenai dasar hukum untuk mengatur hal-hal tertentu belumlah jelas. Oleh karena itu, menjadi janggal secara teori hukum, apabila sebuah aturan selevel Peraturan Menteri mengeliminasi ketentuan atau norma diatasnya, yakni UUJN sementara UUJN tidak memuat perintah untuk aturan lebih lanjut terkait dengan honorarium notaris diatur dalam Peraturan Menteri. Hal ini didasari juga dari UU Nomor 12 Tahun 2011, yang menyebutkan bahwa setiap kelahiran Peraturan Menteri merupakan ketentuan lebih lanjut dari norma hukum diatasnya dengan memperhatikan juga untuk tidak menimbulkan pertentangan norma.

Mengacu pada uraian diatas, disarankan agar Peraturan Menteri itu hendaknya lahir apabila ada norma yang lebih tinggi memerintahkan untuk dibakukan dalam aturan pada level Peraturan Menteri. Namun, apabila tidak ada ketentuan yang mengatur akan hal itu, maka aturan tersebut boleh dimintakan pengujian dikarenakan demi terwujudnya kepastian hukum. Sementara itu, apabila ingin diteruskan Peraturan Menteri tersebut, maka diperlukan evaluasi Peraturan Menteri tersebut dengan

$52 \quad$ Ibid, hlm 48. 
mencarikan dasar hukum yang sepadan untuk mengeliminasi ketentuan UUJN.

\section{Daftar Pustaka}

\section{Buku}

Anshori, Abdul Ghofur, Lembaga Kenotariatan Indonesia Perspektif Hukum dan Etika, (Yogyakarta: UII Press, 2009)

Amiruddin dan Zainal Asikin, Pengantar Metode Penelitian Hukum, (Jakarta: Rajawali Pers, 2014)

Adjie, Habib, Hukum Notaris Indonesia; Tafsir Telematik Terhadap UU Nomor 30 Tahun 2004 Tentang Jabatan Notaris, (Bandung: Rafika Aditama, 2008)

Adji, Habib dan Muhammad Hafidh, Akta Perbankan Syariah Yang Selaras Dengan Pasal 38 UUJN-P, Edisi Revisi, (Semarang: Pustaka Zaman, 2014)

Asshiddiqie, Jimly, Perihal Undang-undang, (Jakarta: Rajawali Pers, 2014)

Darori, Muhammad Irnawan, Hukum Kenotariatan; Pengaturan Jabatan Notaris Berdasarkan Undang-undang Nomor 30 Tahun 2004, (Yogyakarta: Genta Publishing, 2014)

Dirdjosisworo, Soedjono, Pengantar IImu Hukum, (Jakarta: Rajawali Pers, 2016)

Indrati, Maria Farida, IImu Perundang-undangan; Jenis Fungsi dan Materi Muatan, (Yogyakarta: Kanisius, 2014)

Mertokusumo, Sudikno, Bunga Rampai Ilmu Hukum, (Yogyakarta: Liberty, 2010)

Mertokusumo, Sudikno, Mengenal Hukum; Suatu Pengantar, (Yoyakarta: Liberty, 2008)

Mahfud MD, Moh, Konstitusi dan Hukum Dalam Kontroversi Isu, (Jakarta: Rajawali Pers, 2012)

Manan, Abdul, Aspek-aspek Pengubahan Hukum, (Jakarta: Kencana, 2005)

Makarim, Edmon, Notaris dan Transaksi Elektronik; Kajian Hukum Tentang Cybernotary atau Electronic Notary, (Jakarta: Raja Grafindo, 2013)

Purbacaraka, Purnadi dan Soerjono Soekanto, Perihal Kaedah Hukum, (Bandung: PT Citra Aditya Bakti, 1993)

Samekto, FX Adji, Hukum Dalam Lintasan Sejarah, (Bandar Lampung: Indept Publishing, 2013)

Taib, Mukhlis, Dinamika Perundang -Undangan di Indonesia, (Bandung: Refika Aditama, 2017)

Wignjosoebroto, Soetandyo, Hukum Dalam Masyarakat; Perkembangan dan Masalah, (Malang: Bayumedia Publishing, 2008)
Yuliandri, Asas-Asas Pembentukan Peraturan Perudang-Undangan Yang Baik; Gagasan Pembentukan Undang-Undang Berkelanjutan, (Jakarta: Rajawali Pers, 2013)

\section{Makalah/Artikel/Laporan/Hasil Penelitian}

Anand, Ghansham, "Karekteristik Jabatan Notaris di Indonesia dan Batas Tanggung Gugatnya", Disertasi Program Doktor IImu Hukum Fakultas Hukum, Universitas Airlangga; Surabaya, (2013)

Ginting, Budiman, "Kepastian Hukum dan Implikasinya Terhadap Pertumbuhan Investasi di Indonesia", Pidato Pengukuhan Jabatan Guru Besar Tetap dalam Bidang Hukum Investasi Pada Fukultas Hukum Universitas Sumatera Utara, Medan, (2008)

Hartono, Sri Redjeki, "Perspektif Hukum Pada Era Teknologi", Pidato Pengukuhan Jabatan Guru Besar Hukum Dagang Pada Fakulas Hukum Universitas Diponegoro, Semarang, (1995)

Hidayat, Arief, "Konsep dan Implementasi Negara Hukum Pancasila Dalam Mengatasi Permasalahan Hukum Nasional", Ceramah Kunci Ketua Mahkamah Konstitusi dalam Seminar Nasional "Konsep dan Implementasi Negara Hukum Pancasila Dalam Mengatasi Permasahanan Hukum Nasional" di Semarang, (30 September 2017)

Malavet, Pedro A, "Caunsel For The Situation; The Latin Notary, A Historical And Comparative Model", Hasting Internasional and Comparative Law Review, Vol. 19: 389, (1996)

Ramelan, Soetomo, "Peranan Notaris Dalam Pembangunan Hukum, Jurnal Hukum dan Pembangunan Universitas Indonesia", Vol 16, No 4 (1986)

Rahardjo, Satjipto, "Meningkatkan Kepastian Hukum dalam Rangka Pelaksanaan Keadilan Berdasarkan Pancasila", Jurnal Hukum dan Pembangunan Universitas Indonesia Vol 18, No. 6 (1988)

Riyanto, Astim, "Notifikasi Hukum Konstitusi Melalui Pendidikan", Jurnal Hukum dan Pembangunan Universitas Indonesia, Vol 38 Nomor 1, (2008)

Saraswati, Retno, "Daulat Presiden Dalam Kabinet Presidensial", Pidato Pengukuhan Jabatan Guru Besar Bidang IImu Hukum Tata Negara Pada Fakulas Hukum Universitas Diponegoro, di Semarang, (2016)

Toryanto, Agustinus Andy, "Konsep Ideal Pelayanan Jasa Notaris Terhadap Orang Tidak Mampu", 
Disertasi Program Doktor Ilmu Hukum Fakultas Hukum, Universitas Diponegoro; Semarang, (2011)

Utama, Yos Johan, "Membangun Peradilan Tata Usaha Negara Yang Berwibawa", Pidato Pengukuhan Jabatan Guru Besar Dalam IImu Hukum Pada Fakulas Hukum Universitas Diponegoro, di Semarang, (2010)

Yusup, Deni K, "Peran Notaris Dalam Praktek Perjanjian Bisnis Di Perbankan Syariah (Tinjauan
Dari Perspektif Hukum Ekonomi Syariah)", Jurnal Al 'Adalah, Vol. XXI, No. 4 (2015)

\section{Internet}

http://portal.ahu.go.id/id/detail/75-beritalainnya/1560-biaya-notaris-untuk-pendirian-ptcuma-rp-1-juta (diakses 6 Oktober 2017)

https://jateng.kemenkumham.go.id/berita-kanwil/ berita-utama/2842-workshop-pelayanankenotariatan (diakses 6 Oktober 2017) 
"Halaman ini dikosongkan" 